University of Wollongong

Research Online

Australian Institute for Innovative Materials -

Papers

Australian Institute for Innovative Materials

$1-1-2017$

Iron and nickel doped $\mathrm{CoSe} 2$ as efficient non precious metal catalysts for oxygen reduction

\author{
Beibei Yu \\ Hubei University \\ Jiayi Jin \\ Hubei University \\ Huimin Wu \\ Hubei University, hw267@uow.edu.au \\ Shengfu Wang \\ Hubei University \\ Qinghua Xia \\ Hubei University
}

See next page for additional authors

Follow this and additional works at: https://ro.uow.edu.au/aiimpapers

Part of the Engineering Commons, and the Physical Sciences and Mathematics Commons

Research Online is the open access institutional repository for the University of Wollongong. For further information contact the UOW Library: research-pubs@uow.edu.au 


\title{
Iron and nickel doped CoSe2 as efficient non precious metal catalysts for oxygen reduction
}

\begin{abstract}
Iron and nickel doped $\mathrm{CoSe} 2$ were prepared by solvothermal method, and they were proved to be ternary chalcogenides by series of physical characterization. The effects of the iron and nickel contents on the oxygen reduction reaction were investigated by electrochemical measurements, and the highest activities were obtained on $\mathrm{Co} 0.7 \mathrm{Fe} 0.3 \mathrm{Se} 2$ and $\mathrm{Co} 0.7 \mathrm{NiO} .3 \mathrm{Se} 2$, respectively. Both $\mathrm{Co} 0.7 \mathrm{Fe} 0.3 \mathrm{Se} 2$ and

$\mathrm{Co} 0.7 \mathrm{Ni0} .3 \mathrm{Se} 2$ presented four-electron pathway. Furthermore, $\mathrm{Co} 0.7 \mathrm{Fe} 0.3 \mathrm{Se} 2$ exhibited more positive cathodic peak potential $(0.564 \mathrm{~V})$ and onset potential $(0.759 \mathrm{~V})$ than these of Co0.7Ni0.3Se2 $(0.558 \mathrm{~V}$ and $0.741 \mathrm{~V}$ ). And $\mathrm{Co} 0.7 \mathrm{Fe} 0.3 \mathrm{Se} 2$ displayed even superior stability and better tolerance to methanol, ethanol and ethylene glycol crossover effects than the commercial Pt/C (20 wt\% Pt).
\end{abstract}

\section{Keywords}

precious, metal, catalysts, iron, oxygen, nickel, reduction, doped, cose2, efficient, non

Disciplines

Engineering | Physical Sciences and Mathematics

\section{Publication Details}

Yu, B., Jin, J., Wu, H., Wang, S., Xia, Q. \& Liu, H. (2017). Iron and nickel doped CoSe2 as efficient non precious metal catalysts for oxygen reduction. International Journal of Hydrogen Energy, 42 236-242.

\section{Authors}

Beibei Yu, Jiayi Jin, Huimin Wu, Shengfu Wang, Qinghua Xia, and Hua-Kun Liu 


\title{
Iron and nickel doped $\mathrm{CoSe}_{2}$ as efficient non precious metal catalysts \\ for oxygen reduction
}

\author{
Beibei $\mathrm{Yu}^{1}$, Jiayi $\mathrm{Jin}^{1}$, Huimin $\mathrm{Wu}^{*}, 1$, Shengfu Wang ${ }^{1}$, Qinghua Xia ${ }^{1}$, Huakun Liu ${ }^{* *, 2}$ \\ ${ }^{1}$ Hubei Collaborative Innovation Center for Advanced Organic Chemical Materials \& Key \\ Laboratory for the Synthesis and Application of Organic Functional Molecules, Ministry of \\ Education \& College of Chemistry \& Chemical Engineering, Hubei University, Wuhan 430062, \\ PR China \\ ${ }^{2}$ Institute for Superconducting \& Electronic Materials, School of Mechanical, Materials and \\ Mechatronics Engineering, University of Wollongong, Wollongong, NSW 2522, Australia
}

\begin{abstract}
Iron and nickel doped $\mathrm{CoSe}_{2}$ were prepared by solvothermal method, and they were proved to be ternary chalcogenides by series of physical characterization. The effects of the iron and nickel contents on the oxygen reduction reaction were investigated by electrochemical measurements, and the highest activities were obtained on $\mathrm{Co}_{0.7} \mathrm{Fe}_{0.3} \mathrm{Se}_{2}$ and $\mathrm{Co}_{0.7} \mathrm{Ni}_{0.3} \mathrm{Se}_{2}$, respectively. Both $\mathrm{Co}_{0.7} \mathrm{Fe}_{0.3} \mathrm{Se}_{2}$ and $\mathrm{Co}_{0.7} \mathrm{Ni}_{0.3} \mathrm{Se}_{2}$ presented four-electron pathway. Furthermore, $\mathrm{Co}_{0.7} \mathrm{Fe}_{0.3} \mathrm{Se}_{2}$ exhibited more positive cathodic peak potential $(0.564 \mathrm{~V})$ and onset potential $(0.759 \mathrm{~V})$ than these of $\mathrm{Co}_{0.7} \mathrm{Ni}_{0.3} \mathrm{Se}_{2}(0.558 \mathrm{~V}$ and $0.741 \mathrm{~V})$. And $\mathrm{Co}_{0.7} \mathrm{Fe}_{0.3} \mathrm{Se}_{2}$ displayed even superior stability and better tolerance to methanol, ethanol and ethylene glycol crossover effects than the commercial Pt/C (20 wt\% Pt).
\end{abstract}

Keywords: Non-noble metal catalyst; Chalcogenide; Electrocatalysis; Oxygen reduction reaction

* Corresponding author. Tel.: 86 18971479006; Fax: 862788663043.

E-mail address: whm267@hubu.edu.cn

** Corresponding author. E-mail address: $\underline{\text { hua liu@uow.edu.au }}$ 


\section{Introduction}

Nowadays, non-precious metal-based electrocatalysts have exhibited promising activities towards oxygen reduction reaction (ORR) [1-4]. Among them, cobalt based selenides $\left(\mathrm{CoSe}_{\mathrm{x}}\right)$ are attracting enormous interest as new ORR electrocatalysts. For example, $\mathrm{CoSe}_{2} / \mathrm{C}$ obtained by Feng et al. [5, 6] showed superior electrocatalytic activity towards ORR with an open circuitry potential of $0.81 \mathrm{~V}$ in $0.5 \mathrm{M} \mathrm{H}_{2} \mathrm{SO}_{4}$, and higher methanol tolerance than that of Pt/C. Susac et al. [7] exhibited that cobalt-selenium (Co-Se) with varying content of Se obtained by magnetron sputtering and chemical methods indicated a electrocatalytic activity towards ORR in an acidic electrolyte.

However, the ORR activities of these materials are still far from proton exchange membrane fuel cells' practical applications [8-11]. To further improve electrocatalytic activity, doping of transition metal is crucial to the Co-based chalcogenides. Zhao et al. [12] exhibited the tungsten doped Co-Se electrocatalysts synthesized by decarbonylation of carbonyl compounds in 1,6-hexanediol solvent, and indicated high ORR electrocatalytic activity in $0.5 \mathrm{M} \mathrm{H}_{2} \mathrm{SO}_{4}$. Nanosized particles of $\mathrm{Ru}_{x} \mathrm{Fe}_{y} \mathrm{Se}_{z}$ were prepared by Solorza-Feria [13] showed higher electrocatalytic activity towards ORR than that of the $\mathrm{Ru}_{\mathrm{x}} \mathrm{Se}_{\mathrm{y}}$.

In order to enhance ORR electrocatalytic activity, two series of ternary non-noble metal chalcogenides were synthesized in this work. The electrocatalytic activity towards ORR and stability of the chalcogenides were investigated in $0.5 \mathrm{M} \mathrm{H}_{2} \mathrm{SO}_{4}$. Furthermore, the relationships between the content of doping transition metals and electrocatalytic activity were investigated.

\section{Experimental}




\subsection{Electrocatalyst synthesis}

All chemicals were purchased from Sigma-Aldrich.

$\mathrm{Co}_{x} \mathrm{Fe}_{1-x} \mathrm{Se}_{2}(x=0.9,0.8,0.7,0.6,0.5)$ were obtained via a solvothermal method. Briefly, 0.291g cobalt nitride hexahydrate $\left(\mathrm{Co}\left(\mathrm{NO}_{3}\right)_{2} \cdot 6 \mathrm{H}_{2} \mathrm{O}\right)$ and different iron (П) sulfate heptahydrat $\left(\mathrm{FeSO}_{4} \cdot 7 \mathrm{H}_{2} \mathrm{O}\right) \quad($ Table $\mathrm{S} 1)$ were dissolved in $30 \mathrm{~mL}$ diethylenetriamine (DETA) and deionized water (DIW) $\left(\mathrm{V}_{\text {DETA }} / \mathrm{V}_{\text {DIW }}=2: 1\right)$. Then, $0.591 \mathrm{~g}$ sodium selenite $\left(\mathrm{Na}_{2} \mathrm{SeO}_{3}\right)$ and $8.5 \mathrm{~mL}$ hydrazine hydrate $\left(\mathrm{N}_{2} \mathrm{H}_{4} \cdot \mathrm{H}_{2} \mathrm{O}\right)$ were added into the solution, and stirred for $30 \mathrm{~min}$. Finally, the mixture was transferred into an autoclave and treated at $140^{\circ} \mathrm{C}$ for $24 \mathrm{~h}$.

$\mathrm{Co}_{x} \mathrm{Ni}_{1-x} \mathrm{Se}_{2}(x=0.9,0.8,0.7,0.6,0.5)$ were prepared by the similar method, only using nickel nitride hexahydrate $\left(\mathrm{Ni}\left(\mathrm{NO}_{3}\right)_{2} \cdot 6 \mathrm{H}_{2} \mathrm{O}\right)$ (Table S2) instead of $\mathrm{FeSO}_{4} \cdot 7 \mathrm{H}_{2} \mathrm{O}$. $\mathrm{CoSe}_{2}$ was prepared with no addition of $\mathrm{FeSO}_{4} \cdot 7 \mathrm{H}_{2} \mathrm{O}$ [14].

\subsection{Characterization}

X-ray diffraction (XRD) experiments were carried out on a GBC MMA X-ray diffractometer with $\mathrm{Cu} \mathrm{K \alpha}$ radiation. X-ray photoelectron spectroscopy (XPS) was performed by an ESCALAB 250Xi device. Scanning electron microscopy (SEM) with energy-dispersive X-ray spectroscopy (EDX) attachment (JSM6510LV) was used to observe the morphological and chemical composition analyses. The specific surface area was measured by a Quantachrome iQ-MP nitrogen adsorption apparatus.

The ORR activities of all catalysts were obtained with a CHI 750E electrochemical workstation $(\mathrm{CH}$ Instrument Company, Shanghai, China). Pt wire and saturated calomel electrode as the counter and reference electrodes, respectively. Rotating disk electrode (RDE, $5 \mathrm{~mm}$ in diameter) loaded with various catalysts was used as the working electrodes. $5 \mathrm{mg}$ catalyst was ultrasonically dispersed in $0.5 \mathrm{~mL}$ Nafion solution. Then, $10 \mu \mathrm{L}(0.1 \mathrm{mg}$ catalyst) suspension was transferred on the RDE. All 
the potentials of this paper were reported with respect to reversible hydrogen electrode (RHE).

\section{Results and discussion}

\subsection{Material characteristics}

Fig. 1 (A) showed the XRD patterns of (a) $\mathrm{Co}_{0.9} \mathrm{Fe}_{0.1} \mathrm{Se}_{2}$, (b) $\mathrm{Co}_{0.8} \mathrm{Fe}_{0.2} \mathrm{Se}_{2}$, (c) $\mathrm{Co}_{0.7} \mathrm{Fe}_{0.3} \mathrm{Se}_{2}$, (d) $\mathrm{Co}_{0.6} \mathrm{Fe}_{0.4} \mathrm{Se}_{2}$ and (e) $\mathrm{Co}_{0.5} \mathrm{Fe}_{0.5} \mathrm{Se}_{2}$, respectively. While Fig. 1 (B) showed the XRD patterns of (a) $\mathrm{Co}_{0.9} \mathrm{Ni}_{0.1} \mathrm{Se}_{2}$, (b) $\mathrm{Co}_{0.8} \mathrm{Ni}_{0.2} \mathrm{Se}_{2}$, (c) $\mathrm{Co}_{0.7} \mathrm{Ni}_{0.3} \mathrm{Se}_{2}$, (d) $\mathrm{Co}_{0.6} \mathrm{Ni}_{0.4} \mathrm{Se}_{2}$ and (e) $\mathrm{Co}_{0.5} \mathrm{Ni}_{0.5} \mathrm{Se}_{2}$, respectively. The observed diffraction peaks could be indexed to $\mathrm{CoSe}_{2}$ (200), (210), (220), (311), (123), (400), (331) and (024) (JCPDS No. 09-234). No additional peaks of other phases had been observed, confirming the substitution of $\mathrm{Fe}$ or $\mathrm{Ni}$ in $\mathrm{CoSe}_{2}$ lattice [15]. The intensity of the peaks reduced with the doping concentration increasing, which indicated the loss of crystallinity due to lattice distortion and smaller crystallite size [15]. However, the ternary Co-Fe-Se or Co-Ni-Se phase had not been investigated. These could due to the phases present in a very small nanocrystal, or overlap of diffraction peaks from $\mathrm{CoSe}_{2}$ phase and Co-Fe-Se or Co-Ni-Se phase $[16,17]$. Among these materials, $\mathrm{Co}_{0.7} \mathrm{Fe}_{0.3} \mathrm{Se}_{2}$ and $\mathrm{Co}_{0.7} \mathrm{Ni}_{0.3} \mathrm{Se}_{2}$ showed better catalytic activity towards ORR than others according to Fig. S2. 

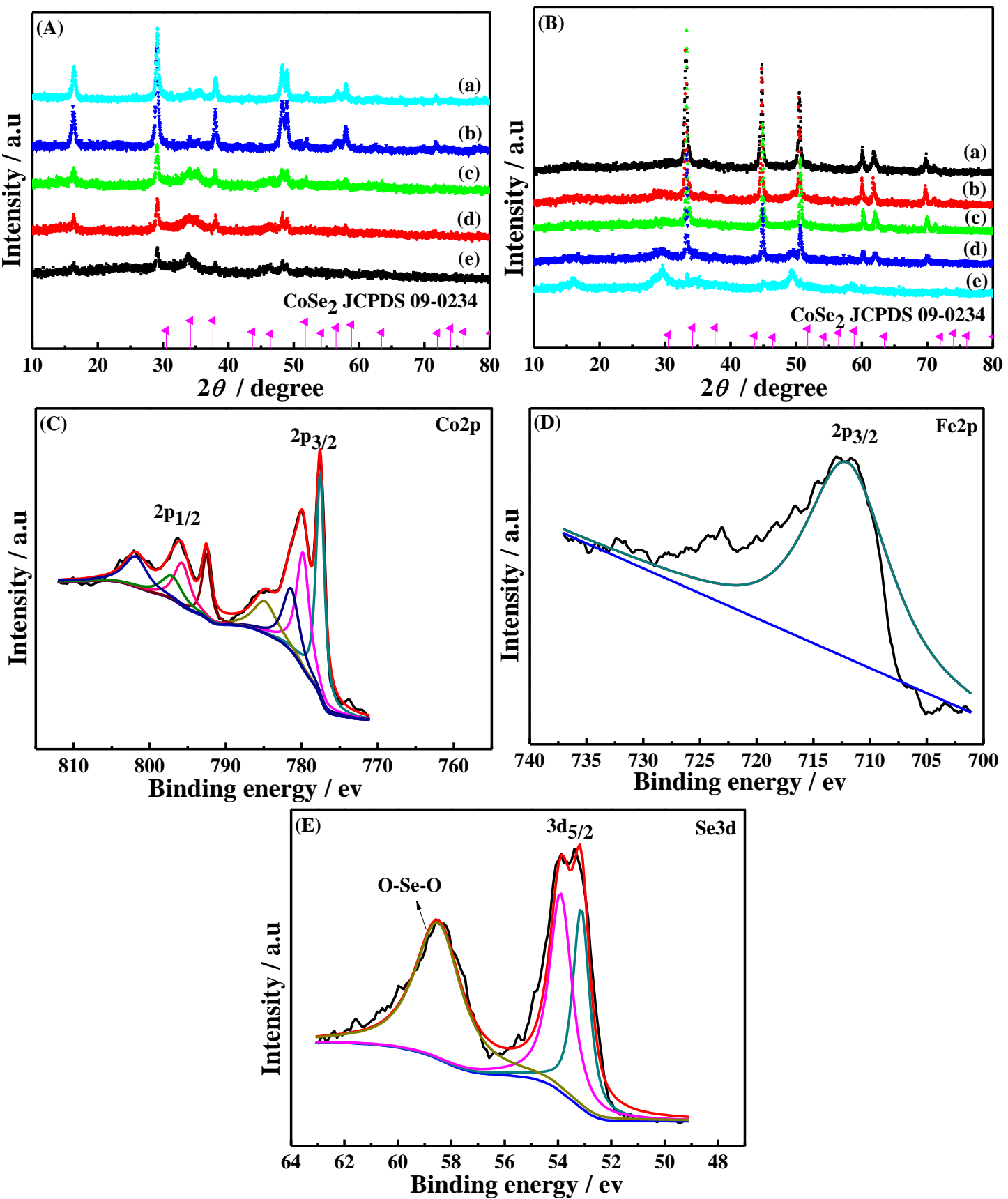

Fig. 1 (A) XRD patterns of (a) $\mathrm{Co}_{0 .} \mathrm{Fe}_{0.1} \mathrm{Se}_{2}$, (b) $\mathrm{Co}_{0.8} \mathrm{Fe}_{0.2} \mathrm{Se}_{2}$, (c) $\mathrm{Co}_{0.7} \mathrm{Fe}_{0.3} \mathrm{Se}_{2}$, (d) $\mathrm{Co}_{0.6} \mathrm{Fe}_{0.4} \mathrm{Se}_{2}$ and (e) $\mathrm{Co}_{0.5} \mathrm{Fe}_{0.5} \mathrm{Se}_{2}$, (B) XRD patterns of (a) $\mathrm{Co}_{0.9} \mathrm{Ni}_{0.1} \mathrm{Se}_{2}$, (b) $\mathrm{Co}_{0.8} \mathrm{Ni}_{0.2} \mathrm{Se}_{2}$, (c) $\mathrm{Co}_{0.7} \mathrm{Ni}_{0.3} \mathrm{Se}_{2}$, (d) $\mathrm{Co}_{0.6} \mathrm{Ni}_{0.4} \mathrm{Se}_{2}$ and (e) $\mathrm{Co}_{0.5} \mathrm{Ni}_{0.5} \mathrm{Se}_{2}$. XPS spectra of $\mathrm{Co}_{0.7} \mathrm{Fe}_{0.3} \mathrm{Se}_{2}$ in the (C) Co 2p, (D) Fe 2p, and (E) Se 3d regions.

The XPS of $\mathrm{Co}_{0.7} \mathrm{Fe}_{0.3} \mathrm{Se}_{2}$ showed that it mainly consisted of $\mathrm{Co}, \mathrm{Fe}$, and $\mathrm{Se}$ elements. Apparently, the binding energy of each element revealed a shift compared with their pure elements. The binding energies of Co $2 \mathrm{p}_{3 / 2}(780.1 \mathrm{eV}$, Fig. 1 (C)) and Fe $2 p_{3 / 2}(711.6$ eV, Fig. 1 (D)) were much higher than binary chalcogenides such as 
$\mathrm{CoSe}_{2}\left(\mathrm{Co} 2 \mathrm{p}_{3 / 2}=778.7 \mathrm{eV}\right)[18,19]$ and iron diselenide $\left(\mathrm{FeSe}_{2}, \mathrm{Fe} 2 \mathrm{p}_{3 / 2}=707.2 \mathrm{eV}\right)$ [20]. However, Se 3d $\mathrm{d}_{5 / 2}$ (Fig. 1 (E)) shifted to more negative binding energy than $\mathrm{CoSe}_{2}\left(\mathrm{Se} 3 \mathrm{~d}_{5 / 2}=54.4 \mathrm{eV}\right)[18,19]$. And the relative amount of Se oxide $(4.06 \%)$ was formed at the $\mathrm{Co}_{0.7} \mathrm{Fe}_{0.3} \mathrm{Se}_{2}$ surface based on XPS analyses. However, the oxide is too small amount that it cannot be detected by XRD. The changes in binding energies for these elements can be explained by the fact that selenium is more electronegative than iron or cobalt. Charge transfer from cobalt and iron to selenium could lead to the chemical shift. So, cobalt and iron moved to positive binding energy, while selenium moved to negative binding energy. The results suggested it was a ternary chalcogenide [21]. Meanwhile, The XPS spectra of $\mathrm{Co}_{0.7} \mathrm{Ni}_{0.3} \mathrm{Se}_{2}$ was shown in Fig. S3. The binding energies of Co $2 \mathrm{p}_{3 / 2}(780.3 \mathrm{eV}$, Fig. S3 (A)) and Ni 2p $3 / 2(855.1 \mathrm{eV}$, Fig. S3 (B)) were much higher than $\mathrm{CoSe}_{2}\left(\mathrm{Co} 2 \mathrm{p}_{3 / 2}=778.7 \mathrm{eV}\right)$ and nickel diselenide $\left(\mathrm{NiSe}_{2}, \mathrm{Ni} 2 \mathrm{p}_{3 / 2}=853.1 \mathrm{eV}\right)[22,23]$. And, selenium shifts to negative binding energy of Se $3 \mathrm{~d}_{5 / 2}$ (Fig. S3 (C)) compared to $\mathrm{CoSe}_{2}\left(\mathrm{Se} 3 \mathrm{~d}_{5 / 2}=54.4 \mathrm{eV}\right)$, indicating that it also was a complete ternary chalcogenide. The relative amount of Se oxide was $2.23 \%$.

SEM of $\mathrm{Co}_{0.7} \mathrm{Ni}_{0.3} \mathrm{Se}_{2}$ and $\mathrm{Co}_{0.7} \mathrm{Fe}_{0.3} \mathrm{Se}_{2}$ were shown in Fig.2 (A) and (B), respectively. $\mathrm{Co}_{0.7} \mathrm{Ni}_{0.3} \mathrm{Se}_{2}$ revealed a fluffy morphology. However, the $\mathrm{Co}_{0.7} \mathrm{Fe}_{0.3} \mathrm{Se}_{2}$ was mainly composed of a huge amount of homogeneous sphere-like shaped particles, so maybe had bigger surface areas. Meanwhile, the specific surface areas of $\mathrm{Co}_{0.7} \mathrm{Ni}_{0.3} \mathrm{Se}_{2}$ and $\mathrm{Co}_{0.7} \mathrm{Fe}_{0.3} \mathrm{Se}_{2}$ were measured to be 35.6 and $43.5 \mathrm{~m}^{2} \cdot \mathrm{g}^{-1}$, respectively. According to report [24], the high specific surface areas could contribute to create abundant active sites, which made them more accessible. Maybe different contents of doped iron or nickel could affect the morphology (Fig. S4). Fig.2 (a) and (b) represented the EDX of $\mathrm{Co}_{0.7} \mathrm{Ni}_{0.3} \mathrm{Se}_{2}$ and $\mathrm{Co}_{0.7} \mathrm{Fe}_{0.3} \mathrm{Se}_{2}$, respectively. The results of EDX (Table 1) were consistent with XPS, which were very close to the design 
results.
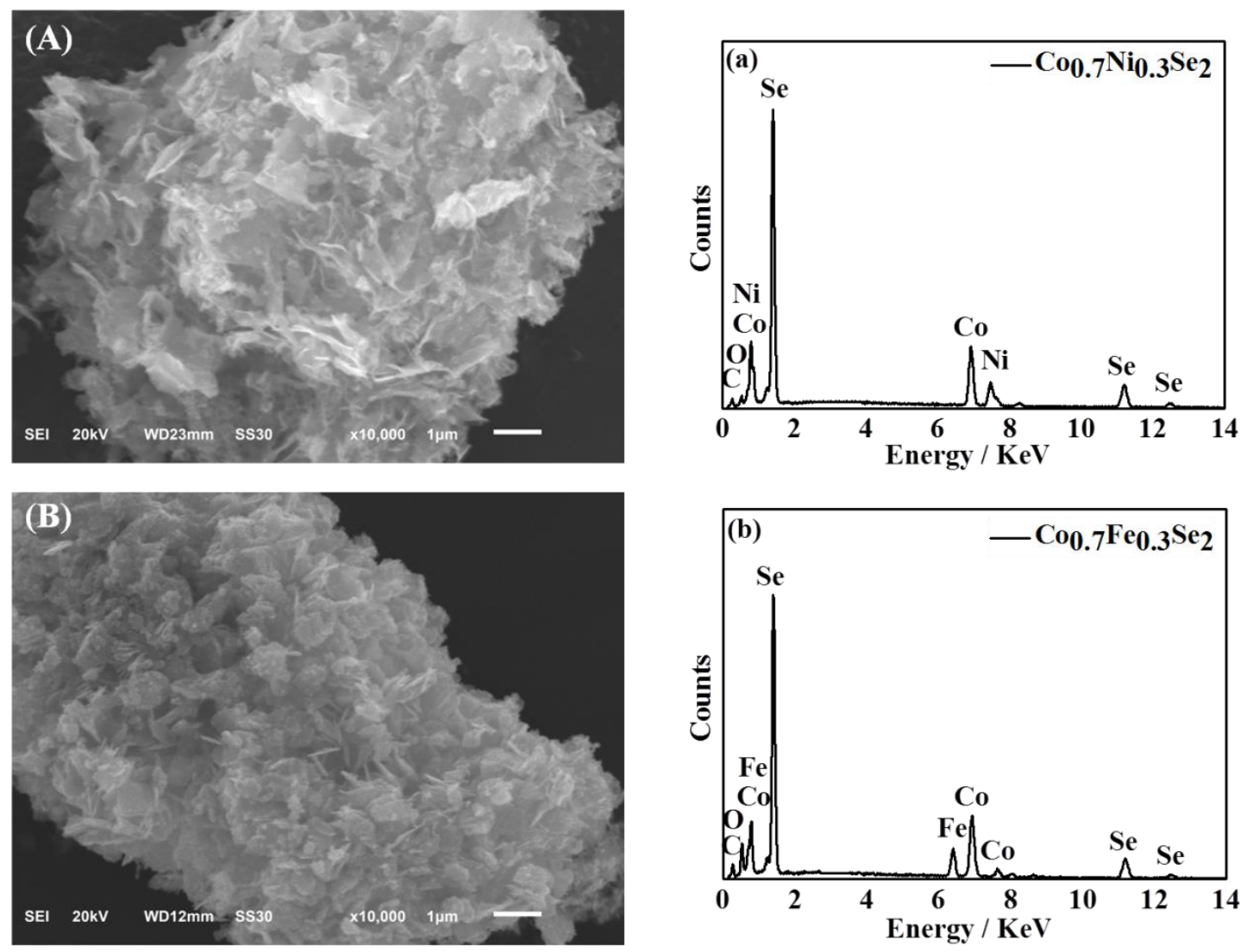

Fig. 2 SEM and EDX images of (A, a) $\mathrm{Co}_{0.7} \mathrm{Ni}_{0.3} \mathrm{Se}_{2}$ and (B, b) $\mathrm{Co}_{0.7} \mathrm{Fe}_{0.3} \mathrm{Se}_{2}$.

Table 1 XPS and EDX analyses of $\mathrm{Co}_{0.7} \mathrm{Fe}_{0.3} \mathrm{Se}_{2}$ and $\mathrm{Co}_{0.7} \mathrm{Ni}_{0.3} \mathrm{Se}_{2}$.

\begin{tabular}{ccccc|cccc}
\hline \multirow{2}{*}{ Sample } & \multicolumn{4}{c|}{ XPS (at. \%) } & \multicolumn{4}{c}{ EDX (at. \%) } \\
\cline { 2 - 9 } & $\mathrm{Co}$ & $\mathrm{Fe}$ & $\mathrm{Ni}$ & $\mathrm{Se}$ & $\mathrm{Co}$ & $\mathrm{Fe}$ & $\mathrm{Ni}$ & $\mathrm{Se}$ \\
\hline $\mathrm{Co}_{0.7} \mathrm{Fe}_{0.3} \mathrm{Se}_{2}$ & 11.07 & 5.03 & -- & 22.66 & 11.08 & 5.07 & -- & 22.70 \\
$\mathrm{Co}_{0.7} \mathrm{Ni}_{0.3} \mathrm{Se}_{2}$ & 4.47 & -- & 2.06 & 11.42 & 4.52 & -- & 2.12 & 11.83 \\
\hline
\end{tabular}

\subsection{Electrochemical characterization}

Linear sweep voltammetry (LSV) measurements were shown in Fig. 3 (A). The onset potential $\left(\mathrm{E}_{\mathrm{ORR}}\right)$ was defined as potential at which the current density was equal to zero. And the half-wave potential $\left(\mathrm{E}_{1 / 2}\right)$, when the current density was equal to half of the limiting diffusion current density, was extracted from the polarization curve. 
The more positive EORR and $\mathrm{E}_{1 / 2}$ were, the better electrocatalytic activity towards ORR they showed [25]. Except for $\mathrm{Pt} / \mathrm{C}, \mathrm{Co}_{0.7} \mathrm{Fe}_{0.3} \mathrm{Se}_{2}$ exhibited more positive EORR and $\mathrm{E}_{1 / 2}$ compared with $\mathrm{CoSe}_{2}$ and $\mathrm{Co}_{0.7} \mathrm{Ni}_{0.3} \mathrm{Se}_{2}$, suggesting a much better ORR activity, and the parameters were listed in Table 2. Previous reports showed that the doping of Fe on Co-based chalcogenides could improve the constitution and stabilization of the catalytically active species, resulting in favorable ORR performance [26].

The durabilities of $\mathrm{CoSe}_{2}, \mathrm{Co}_{0.7} \mathrm{Ni}_{0.3} \mathrm{Se}_{2}$ and $\mathrm{Co}_{0.7} \mathrm{Fe}_{0.3} \mathrm{Se}_{2}$ were also analyzed by Cyclic voltammograms (CVs), and selected the current densities of different cycles to draw the Fig. 3 (B). Obviously, $\mathrm{Co}_{0.7} \mathrm{Fe}_{0.3} \mathrm{Se}_{2}$ and $\mathrm{Co}_{0.7} \mathrm{Ni}_{0.3} \mathrm{Se}_{2}$ showed excellent long-term performance. Furthermore, the maximum current densities values of the $\mathrm{Co}_{0.7} \mathrm{Fe}_{0.3} \mathrm{Se}_{2}$ were higher than those of the $\mathrm{CoSe}_{2}$ and $\mathrm{Co}_{0.7} \mathrm{Ni}_{0.3} \mathrm{Se}_{2}$. The electrochemical stability of the catalyst might be related to the amount of selenium on the $\mathrm{CoSe}_{2}$. It had been reported that selenium can play a role in protecting the electrochemical oxidation of metals in chalcogenide compounds [27]. And the presence of Se oxide could also prevent dissolution in $\mathrm{O}_{2}$-saturated $0.5 \mathrm{M} \mathrm{H}_{2} \mathrm{SO}_{4}$, which might contribute to its excellent stability [28]. At the same time, Fe or Ni doped the $\mathrm{CoSe}_{2}$ increased adsorption/desorption of metals compounds associated with microporous structure $[29,30]$.

A series of LSV curves recorded from 100 to $2500 \mathrm{rpm}$ were obtained in Fig. 3 (C). Koutecky-Levich (K-L) plots at different potentials showed good linearity (Fig. 3 (D)), revealing first-order reaction kinetics towards the concentration of dissolved oxygen [31]. The electron transfer number (n) could be calculated from the following K-L equations (1) [32], and n was calculated to be 4:

$$
j^{-1}=j_{k}^{-1}+j_{d}^{-1}=j_{k}^{-1}+\left(\mathrm{B} \omega^{1 / 2}\right)^{-1}
$$

where $j, j_{d}$ and $j_{k}$ were the measured, diffusion-limited and kinetic current densities, $\omega$ 
represented the electrode rotating rate. $\mathrm{Co}_{0.7} \mathrm{Fe}_{0.3} \mathrm{Se}_{2}, \mathrm{Co}_{0.7} \mathrm{Ni}_{0.3} \mathrm{Se}_{2}$ and $\mathrm{Pt} / \mathrm{C}$ showed a direct $4 \mathrm{e}^{-}$reduction process towards ORR (Table 2) [33], while other $\mathrm{Co}_{x} \mathrm{Fe}_{1-x} \mathrm{Se}_{2}$ and $\mathrm{Co}_{x} \mathrm{Ni}_{1-x} \mathrm{Se}_{2}$ (Fig. S5) with different iron or nickel contents exhibited a mixed four-electron and two-electron reduction processes with $\mathrm{H}_{2} \mathrm{O}_{2}$ as the intermediate agent. The corresponding values of $j_{k}$ and $\mathrm{n}$ were shown in Fig. S6 (B, D). The electronic structure of the transition metal was usually expressed by a percentage of $d$ orbital in the metal bond $(\mathrm{d} \%)$. The higher value of $\mathrm{d} \%$ was, the more electrons filling in corresponding d energy band was, leading to less holes. The $\mathrm{d} \%$ of the transition metal in the order of $\mathrm{Ni}(40)>\mathrm{Co}(39.7)>\mathrm{Fe}(39.5)$. When the smaller values (d\%) of the metal $(\mathrm{Fe})$ added to $\mathrm{CoSe}_{2}$, the bigger $\mathrm{d} \%$ of $\mathrm{Co}$ atoms was transferred to smaller $\mathrm{d} \%$ of the Fe atoms. Which increased the holes of Co, and improved the adsorption rate of oxygen. Although the difference between iron and nickel was very small, the d\% of Ni was bigger than Co [34]. Therefore, the bonding ability of $\mathrm{Co}_{0.7} \mathrm{Fe}_{0.3} \mathrm{Se}_{2}$ was higher than that of $\mathrm{Co}_{0.7} \mathrm{Ni}_{0.3} \mathrm{Se}_{2}$, implying $\mathrm{Co}_{0.7} \mathrm{Fe}_{0.3} \mathrm{Se}_{2}$ presented better ORR activity.

Fig. 3 (E) showed the tafel plots of the $\mathrm{Co}_{0.7} \mathrm{Fe}_{0.3} \mathrm{Se}_{2}, \mathrm{Co}_{0.7} \mathrm{Ni}_{0.3} \mathrm{Se}_{2}$ and $\mathrm{CoSe}_{2}$ towards ORR. The $j_{k}$ were calculated using K-L equation, $\mathrm{Co}_{0.7} \mathrm{Fe}_{0.3} \mathrm{Se}_{2}$ exhibited a highest value than that of $\mathrm{Co}_{0.7} \mathrm{Ni}_{0.3} \mathrm{Se}_{2}$ and $\mathrm{CoSe}_{2}$. The tafel slope $(b)$ and transfer coefficient $(\alpha)$ were listed in Table 2 . The highest ORR activity of $\mathrm{Co}_{0.7} \mathrm{Fe}_{0.3} \mathrm{Se}_{2}$ was further supported by the smallest tafel slope of $110 \mathrm{mV} / \mathrm{decade}$ among $\mathrm{CoSe}_{2}$, $\mathrm{Co}_{x} \mathrm{Fe}_{1-\mathrm{x}} \mathrm{Se}_{2}$ and $\mathrm{Co}_{x} \mathrm{Ni}_{1-\mathrm{x}} \mathrm{Se}_{2}$ with different iron or nickel contents (Fig. S6 (A, C)). Which indicated that the ORR on $\mathrm{Co}_{0.7} \mathrm{Fe}_{0.3} \mathrm{Se}_{2}$ was controlled by the first electron transfer process, similar to that of the Pt/C (Fig. S6 (E)) [35]. Moreover, the results were comparable or even better than other catalysts in Table 2. It might be due to the doped Fe increased the surface area, adsorption/desorption of metals compounds, and 
electron transport between electrode substrate and electrolyte interface [29, 30].
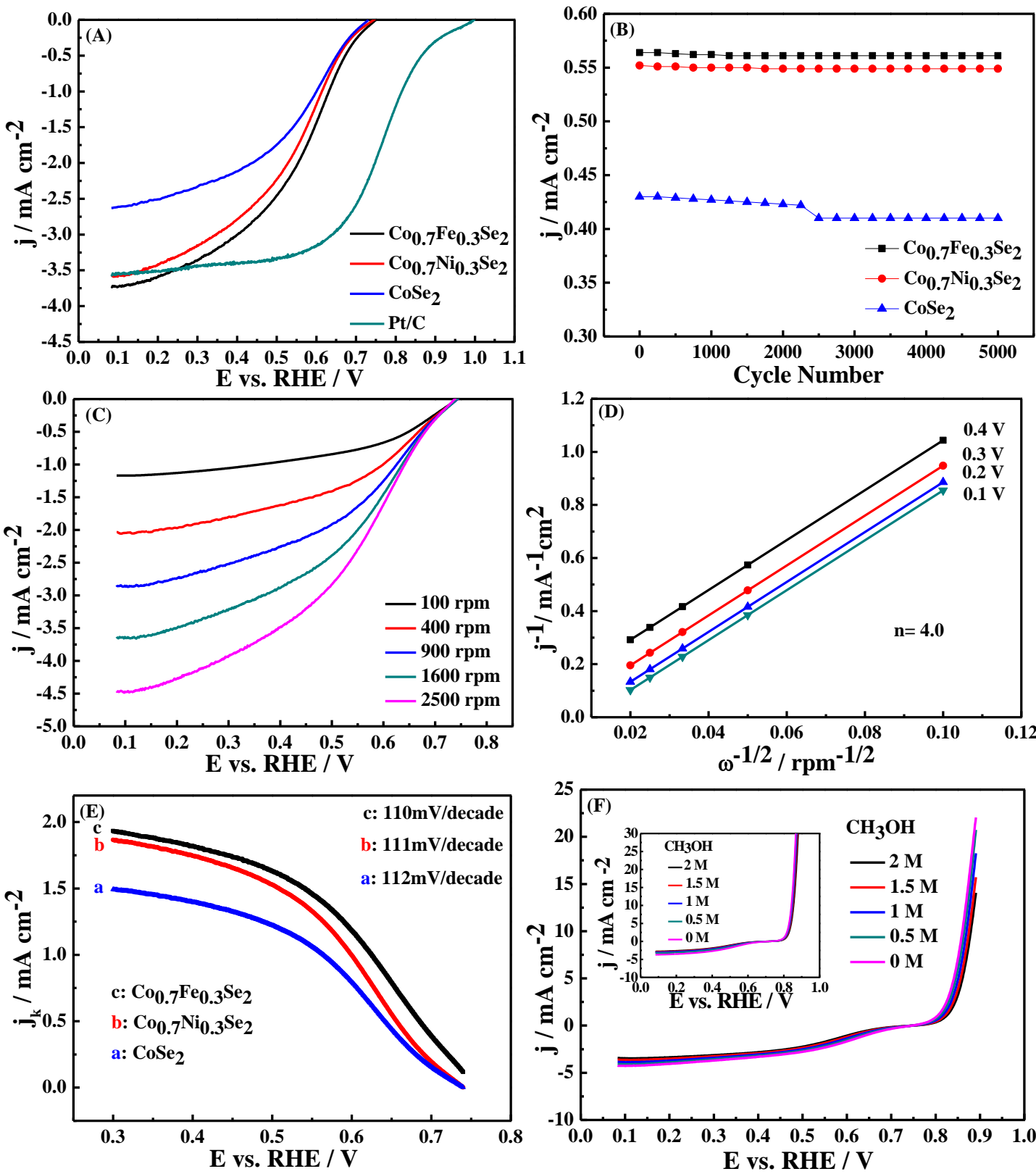

Fig. 3 (A) LSV curves of $\mathrm{Pt} / \mathrm{C}, \mathrm{CoSe}_{2}, \mathrm{Co}_{0.7} \mathrm{Ni}_{0.3} \mathrm{Se}_{2}$ and $\mathrm{Co}_{0.7} \mathrm{Fe}_{0.3} \mathrm{Se}_{2}$ in $\mathrm{O}_{2}$-saturated $0.5 \mathrm{M}$ $\mathrm{H}_{2} \mathrm{SO}_{4}$ at $1600 \mathrm{rpm}$ and a scan rate of $10 \mathrm{mV} \mathrm{s}^{-1}$. (B) The maximum current densities of $\mathrm{CoSe}_{2}$, $\mathrm{Co}_{0.7} \mathrm{Ni}_{0.3} \mathrm{Se}_{2}$ and $\mathrm{Co}_{0.7} \mathrm{Fe}_{0.3} \mathrm{Se}_{2}$ recorded during repeated cycling by CVs. (C) LSV curves of the $\mathrm{Co}_{0.7} \mathrm{Fe}_{0.3} \mathrm{Se}_{2}$ in $\mathrm{O}_{2}$-saturated $0.5 \mathrm{M} \mathrm{H}_{2} \mathrm{SO}_{4}$ at different rotation rates. (D) $\mathrm{K}$-L plots of $\mathrm{Co}_{0.7} \mathrm{Fe}_{0.3} \mathrm{Se}_{2}$ at various potentials. (E) Tafel polts of $\mathrm{CoSe}_{2}, \mathrm{Co}_{0.7} \mathrm{Ni}_{0.3} \mathrm{Se}_{2}$ and $\mathrm{Co}_{0.7} \mathrm{Fe}_{0.3} \mathrm{Se}_{2}$ at $1600 \mathrm{rpm}$. (F) LSV curves of $\mathrm{Co}_{0.7} \mathrm{Fe}_{0.3} \mathrm{Se}_{2}$ in $\mathrm{O}_{2}$-saturated $0.5 \mathrm{M} \mathrm{H}_{2} \mathrm{SO}_{4}$ containing $\mathrm{CH}_{3} \mathrm{OH}(0-2$ $\mathrm{M}), \mathrm{Co}_{0.7} \mathrm{Ni}_{0.3} \mathrm{Se}_{2}$ was shown in corresponding inset.

Table 2 Comparison of catalytic activity data with $\mathrm{Co}_{x} \mathrm{Fe}_{1-x} \mathrm{Se}_{2}, \mathrm{Co}_{x} \mathrm{Ni}_{1-x} \mathrm{Se}_{2}, \mathrm{CoSe}_{2}$ 
$\mathrm{Pt} / \mathrm{C}$ and other catalysts reported in the literature based ORR catalysts.

\begin{tabular}{ccccccc}
\hline Catalyst & EORR & $\mathrm{E}_{1 / 2}$ & $\mathrm{n}$ & $-b$ & $\alpha$ & $\left|j_{k}\right|$ at $0.3 \mathrm{~V}$ \\
\hline $\mathrm{Co}_{0.9} \mathrm{Fe}_{0.1} \mathrm{Se}_{2}$ & 0.740 & 0.576 & 3.3 & 121 & 0.625 & 1.440 \\
$\mathrm{Co}_{0.8} \mathrm{Fe}_{0.2} \mathrm{Se}_{2}$ & 0.747 & 0.582 & 3.9 & 117 & 0.639 & 1.722 \\
$\mathrm{Co}_{0.7} \mathrm{Fe}_{0.3} \mathrm{Se}_{2}$ & 0.759 & 0.584 & 4.0 & 110 & 0.645 & 1.830 \\
$\mathrm{Co}_{0.6} \mathrm{Fe}_{0.4} \mathrm{Se}_{2}$ & 0.745 & 0.580 & 3.8 & 119 & 0.635 & 1.672 \\
$\mathrm{Co}_{0.5} \mathrm{Fe}_{0.5} \mathrm{Se}_{2}$ & 0.737 & 0.573 & 3.2 & 125 & 0.622 & 1.437 \\
$\mathrm{Co}_{0.9} \mathrm{Ni}_{0.1} \mathrm{Se}_{2}$ & 0.736 & 0.499 & 3.8 & 117 & 0.617 & 1.777 \\
$\mathrm{Co}_{0.8} \mathrm{Ni}_{0.2} \mathrm{Se}_{2}$ & 0.739 & 0.552 & 3.9 & 116 & 0.626 & 1.790 \\
$\mathrm{Co}_{0.7} \mathrm{Ni}_{0.3} \mathrm{Se}_{2}$ & 0.741 & 0.556 & 4.0 & 111 & 0.640 & 1.827 \\
$\mathrm{Co}_{0.6} \mathrm{Ni}_{0.4} \mathrm{Se}_{2}$ & 0.733 & 0.489 & 2.8 & 120 & 0.558 & 1.211 \\
$\mathrm{Co}_{0.5} \mathrm{Ni}_{0.5} \mathrm{Se}_{2}$ & 0.731 & 0.485 & 2.4 & 121 & 0.543 & 1.036 \\
$\mathrm{CoSe}_{2}$ & 0.708 & 0.560 & 3.9 & 112 & 0.638 & 1.522 \\
$\mathrm{Pt}_{/ \mathrm{C}}$ & 0.934 & 0.760 & 4.0 & 110 & 0.847 & 1.871 \\
$\mathrm{~W}_{-\mathrm{Co}_{-} \mathrm{Se}_{2}[21]}$ & 0.755 & - & 2.0 & 113 & - & - \\
$\mathrm{Ru}_{x} \mathrm{Moo}_{y} \mathrm{Se}_{z}[38]$ & 0.740 & - & 4.0 & 116 & 0.520 & - \\
$\mathrm{Ru}_{x} \mathrm{Cr}_{y} \mathrm{Se}_{z}[39]$ & 0.800 & - & 4.0 & 116 & 0.510 & - \\
$\mathrm{CoSe}_{3} \mathrm{O}_{4} / \mathrm{CoS}_{2}[5]$ & 0.720 & - & - & 125 & - & - \\
$\mathrm{Co}_{7} \mathrm{Se}_{8}[40]$ & 0.811 & - & 3.9 & 121 & - & - \\
\hline
\end{tabular}

The satisfactory catalyst towards ORR should exhibit superior tolerance to the fuels (such as methanol, ethanol and ethylene glycol), which could penetrate the membrane from the anode [14]. We measured the LSV of $\mathrm{Co}_{0.7} \mathrm{Fe}_{0.3} \mathrm{Se}_{2}$ (Fig. 3 (F), S7 (C, E)), $\mathrm{Co}_{0.7} \mathrm{Ni}_{0.3} \mathrm{Se}_{2}$ (Fig. 3 (F) (inset), S7 (D, F)) and Pt/C (Fig. S7 (A, B, G)) in $\mathrm{O}_{2}$-saturated 0.5 $\mathrm{M} \mathrm{H}_{2} \mathrm{SO}_{4}$ containing 0-2 $\mathrm{M}$ methanol, ethanol and ethylene glycol, respectively. Compared with $\mathrm{CoSe}_{2}$ [14], $\mathrm{Co}_{0.7} \mathrm{Fe}_{0.3} \mathrm{Se}_{2}$ and $\mathrm{Co}_{0.7} \mathrm{Ni}_{0.3} \mathrm{Se}_{2}$ showed little activity loss and had favorable tolerance to the methanol, ethanol and ethylene glycol. In contrast, there was an obvious decrease in the ORR activity of $\mathrm{Pt} / \mathrm{C}$, because of the 
competitive reaction between oxygen reduction and methanol, ethanol and ethylene glycol oxidation [36, 37].

\section{Conclusions}

In summary, $\mathrm{Fe}$ and $\mathrm{Ni}$ doped $\mathrm{CoSe}_{2}$ were successfully synthesized. The ORR catalytic activity of $\mathrm{Co}_{x} \mathrm{Fe}_{1-x} \mathrm{Se}_{2}$ and $\mathrm{Co}_{x} \mathrm{Ni}_{1-x} \mathrm{Se}_{2}$ catalysts changed with iron or nickel contents. As a result, $\mathrm{Co}_{0.7} \mathrm{Fe}_{0.3} \mathrm{Se}_{2}$ demonstrated an excellent electroactivity and durability towards ORR, making it a promising non-noble metal electrocatalyst for full cells.

\section{Acknowledgements}

This work was supported by the National Natural Science Foundation of China through a project entitled "The synthesis of Pt-M/C nanoparticles and construction of non-enzymatic electrochemical biosensor" (Grant No. 21205030), and by State Key Laboratory of Advanced Technology for Materials Synthesis and Processing (Wuhan University of Technology, 2015-KF-13), and by Hubei Key Laboratory of Pollutant Analysis \& Reuse Technology (PA160104), and from the Natural Science Fund for

Creative Research Groups of Hubei Province of China through a project entitled "Controllable Synthesis and Application of Nano-/microsized Functional Materials"(2014CFA015).

\section{References}

[1] Solorza-Feria O, Ellmer K, Gierstig M, Alonso-Vante N. Novel low-temperature synthesis of semiconducting transition metal chalcogenide electrocatalyst for multielectron charge transfer: molecular oxygen reduction. Electrochim Acta 
1994; 39: 1647-1653.

[2] Cheng H, Yuan W, Scott K. A liquid-gas phase mixed-reactant fuel cell with a RuSeW cathode electrocatalyst. J Power Sources 2008; 183: 678-681.

[3] Gago AS, Morales-Acosta D, Arriaga LG, Alonso-Vante N. Carbon supported ruthenium chalcogenide as cathode catalyst in a microfluidic formic acid fuel cell. J Power Sources 2011; 196: 1324-1328.

[4] Ganesan P, Prabu M, Sanetuntikul J, Shanmugam S. Cobalt sulfide nanoparticles grown on nitrogen and sulfur codoped graphene oxide: an efficient electrocatalyst for oxygen reduction and evolution reactions. ACS Catal 2015; 5: 3625-3637.

[5] Feng YJ, He T, Alonso-Vante N. In situ Free-Surfactant synthesis and ORR-electrochemistry of carbon-supported $\mathrm{Co}_{3} \mathrm{~S}_{4}$ and $\mathrm{CoSe}_{2}$ nanoparticles. Chem Mat 2008; 20: 26-28.

[6] Feng YJ, He T, Alonso-Vante N. Carbon-supported $\mathrm{CoSe}_{2}$ nanoparticles for oxygen reduction reaction in acid medium. Fuel Cells 2010; 10: 77-83.

[7] Susac D, Sode A, Zhu L, Wong PC, Teo M, Bizzotto D, Mitchell KAR, Parsons R R, Campbell SA. A methodology for investigating new nonprecious metal catalysts for PEM fuel cells. J Phys Chem B 2006; 110: 10762-10770.

[8] Othman R, Dicks AL, Zhu ZH. Non precious metal catalysts for the PEM fuel cell cathode. Int J Hydrogen Energy 2012; 37: 357-372.

[9] Chao YS, Tsai DS, Wu AP, Tseng LW, Huang YS. Cobalt selenide electrocatalyst supported by nitrogen-doped carbon and its stable activity toward oxygen reduction reaction. Int J Hydrogen Energy 2013; 38: 5655-5664.

[10] He XB, Yin FX, Li G. A Co/metaleorganic-framework bifunctional electrocatalyst: The effect of the surface cobalt oxidation state on oxygen 
evolution/reduction reactions in an alkaline electrolyte. Int J Hydrogen Energy 2015; 40: 9713-9722.

[11] Chiao SP, Tsai DS, Wilkinson DP, Chen YM, Huang YS. Carbon supported $\mathrm{Ru}_{1-x} \mathrm{Fe}_{x} \mathrm{Se}_{y}$ electrocatalysts of pyrite structure for oxygen reduction reaction. Int J Hydrogen Energy 2010; 35: 6508-6517.

[12] Zhao DJ, Zhang S, Yin GP, Du CY, Wang ZB, Wei J. Tungsten doped Co-Se nanocomposites as an efficient non precious metal catalyst for oxygen reduction. Electrochim Acta 2013; 91: 179-184.

[13] González-Huerta RG, Chavez-Carvayár JA, Solorza-Feria O. Electrocatalysis of oxygen reduction on carbon supported Ru-based catalysts in a polymer electrolyte fuel cell. J Power Sources 2006; 153: 11-17.

[14] Yu BB, Wu WQ, Jin JY, Wu HM, Wang SF, Xia QH. Facile synthesis of Co-based selenides for oxygen reduction reaction in acidic medium. Int $\mathrm{J}$ Hydrogen Energy 2016; 41: 8863-8870.

[15] Kumar S, Verma NK. Structural, optical and magnetic investigations on Fe-doped ZnS nanoparticles. J Mater Sci: Mater Electron 2015; 26: 2754-2759.

[16] Byskov LS, Hammer B, Norskov JK, Clausen BS, Topsoe H. Sulfur bonding in $\mathrm{MoS}_{2}$ and Co-Mo-S structures. Catal Lett 1997; 47: 177-182.

[17] Yoosuk B, Song C, Kim JH, Ngamcharussrivichai C, Prasassarakich P. Effects of preparation conditions in hydrothermal synthesis of highly active unsupported NiMo sulfide catalysts for simultaneous hydrodesulfurization of dibenzothiophene and 4,6-dimethyldibenzothiophene. Catal Today 2010; 149: $52-61$

[18] Gao J, Zhang B, Zhang X, Xu B. Magnetic-dipolar-interactioninduced self-assembly affords wires of hollow nanocrystals of cobalt selenide. Angew 
Chem Int Ed 2006; 45: 1220-1223.

[19] Najafpour MM, Hosseini SM, Tavahodi M, Ghobadi MZ. The conversion of $\mathrm{CoSe}_{2}$ to $\mathrm{Co}$ oxide under the electrochemical water oxidation condition. Int $\mathrm{J}$ Hydrogen Energy 2016; 41: 13469-13475.

[20] Huang SS, He QQ, Chen WL, Zai JT, Qiao QQ, Qian XF. 3D hierarchical FeSe $\mathrm{Se}_{2}$ microspheres: Controlled synthesis and applications in dye-sensitized solar cells. Nano Energy 2015; 15: 205-215.

[21] Lee K, Zhang L, Zhang JJ. Ternary non-noble metal chalcogenide (W-Co-Se) as electrocatalyst for oxygen reduction reaction. Electrochem Commun 2007; 9: 1704-1708.

[22] Van der Heide H, Hermel R, Vanbruggen CF, Haas C. X-ray photoelectron spectra of 3d transition metal pyrites. J Solid State Chem 1980; 33: 17-25.

[23] Yang J, Cheng GH, Zeng JH, Yu SH, Liu XM, Qian YT. Shape control and characterization of transition metal diselenides $\mathrm{MSe}_{2}(\mathrm{M}=\mathrm{Ni}, \mathrm{Co}, \mathrm{Fe})$ prepared by a solvothermal-reduction process. Chem Mater 2001; 13: 848-853.

[24] Zhang Y, Huang LB, Jiang WJ, Zhang X, Chen YY, Wei Z, Wan LJ, Hu JS. Sodium chloride-assisted green synthesis of a 3D Fe-N-C hybrid as a highly active electrocatalyst for the oxygen reduction reaction. J Mater Chem A 2016; 4: 7781-7787.

[25] Lu J, Bo XJ, Wang H, Guo LP. Nitrogen-doped ordered mesoporous carbons synthesized from honey as metal-free catalyst for oxygen reduction reaction. Electrochim Acta 2013; 108: 10-16.

[26] Zhao ZL, Wu HX, He HL, Xu XL, Jin YD. Self-standing non-noble metal (Ni-Fe) oxide nanotube array anode catalysts with synergistic reactivity for high-performance water oxidation. J Mater Chem A 2015; 3: 7179-7186. 
[27] Bron M, Bogdanoff P, Fiechter S, Dorbandt I, Hilgendorff M, Schulenburg H, Tributsch $H$. Influence of selenium on the catalytic properties of ruthenium-based cluster catalysts for oxygen reduction. J Electroanal Chem 2001; 500: 510-517.

[28] Li HY, Gao D, Cheng X. Simple microwave preparation of high activity Se-rich $\mathrm{CoSe}_{2} / \mathrm{C}$ for oxygen reduction reaction. Electrochim Acta 2014; 138: 232-239.

[29] Liu XJ, Xu ZZ, Ahn HJ, Lyu SK, Ahn IS. Electrochemical characteristics of cathode materials $\mathrm{NiS}_{2}$ and Fe-doped $\mathrm{NiS}_{2}$ synthesized by mechanical alloying for lithium-ion batteries. Powder Technol 2012; 229: 24-29.

[30] Sivanantham A, Ganesan P, Shanmugam S. Hierarchical $\mathrm{NiCo}_{2} \mathrm{~S}_{4}$ nanowire arrays supported on Ni foam: an efficient and durable bifunctional electrocatalyst for oxygen and hydrogen evolution reactions. Adv Funct Mater 2016; 26: 4661-4672.

[31] Liang YY, Li YG, Wang HL, Zhou JG, Wang J, Regier T, Dai HJ. $\mathrm{Co}_{3} \mathrm{O}_{4}$ nanocrystals on graphene as a synergistic catalyst for oxygen reduction reaction. Nat Mater 2011; 10: 780-786.

[32] Zhang S, Shao YY, Yin GP, Lin YH. Stabilization of platinum nanoparticle electrocatalysts for oxygen reduction using poly(diallyldimethylammonium chloride). J Mater Chem 2009; 19: 7995-8001.

[33] Chen P, Wang LK, Wang G, Gao MR, Ge J, Yuan WJ, Shen YH, Xie AJ, Yu, SH. Nitrogen-doped nanoporous carbon nanosheets derived from plant biomass: an efficient catalyst for oxygen reduction reaction. Energy Environ Sci 2014; 7: 4095-4103.

[34] Alonso-Vante N, Malakhov IV, Nikitenko SG, Savinova ER, Kochubey DI. The structure analysis of the active centers of Ru-containing electrocatalysts for the 
oxygen reduction. An in situ EXAFS study. Electrochim Acta 2002; 47: 3807-3814.

[35] Solorza-Feria O, Ellmer K, Giersig M, Alonso-Vante N. Novel low-temperature synthesis of semiconducting transition metal chalcogenide electrocatalyst for multielectron charge transfer: molecular oxygen reduction. Electrochim Acta 1994; 39: 1647-1653.

[36] Yang H, Alonso-Vante N, Leger JM, Lamy C. Tailoring, structure, and activity of carbon-supported nanosized Pt-Cr alloy electrocatalysts for oxygen reduction in pure and methanol-containing electrolytes. J Phys Chem B 2004; 108: 1938-1947.

[37] Li Y, Zhou W, Wang H, Xie L, Liang Y, Wei F, Idrobo JC, Pennycook SJ, Dai H. An oxygen reduction electrocatalyst based on carbon nanotube-graphene complexes. Nat Nanotechnol 2012; 7: 394-400.

[38] Suárez-Alcántara K, Solorza-Feria O. Kinetics and PEMFC performance of $\mathrm{Ru}_{x} \mathrm{Mo}_{y} \mathrm{Se}_{z}$ nanoparticles as a cathode catalyst. Electrochimica Acta 2008; 53: 4981-4989.

[39] Suárez-Alcántara K, Rodríguez-Castellanos A, Dante R, Solorza-Feria O. $\mathrm{Ru}_{x} \mathrm{Cr}_{y} \mathrm{Se}_{z}$ electrocatalyst for oxygen reduction in a polymer electrolyte membrane fuel cell. J Power Sources 2006; 157: 114-120.

[40] Masud J, Nath M. $\mathrm{Co}_{7} \mathrm{Se}_{8}$ nanostructures as catalysts for oxygen reduction reaction with high methanol tolerance. ACS Energy Lett 2016; 1: 27-31.

[41] Gao MR, Liu S, Jiang J, Cui CH, Yao WT, Yu SH. In situ controllable synthesis of magnetite nanocrystals/ $\mathrm{CoSe}_{2}$ hybrid nanobelts and their enhanced catalytic performance. J Mater Chem 2010; 20: 9355-9361. 


\section{Supporting Information}

Table of contents

I The prepared materials corresponding to the precursors' amounts of $\mathrm{FeSO}_{4} \cdot 7 \mathrm{H}_{2} \mathrm{O}$ and $\mathrm{Ni}\left(\mathrm{NO}_{3}\right)_{2} \cdot 6 \mathrm{H}_{2} \mathrm{O}$

II CVs, LSV and Nyquist plots of $\mathrm{Co}_{x} \mathrm{Fe}_{1-x} \mathrm{Se}_{2}$ and $\mathrm{Co}_{x} \mathrm{Ni}_{1-x} \mathrm{Se}_{2}$

IIIXPS spectra of $\mathrm{Coo}_{7} \mathrm{Ni}_{0.3} \mathrm{Se}_{2}$

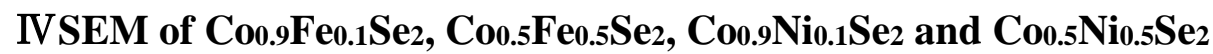

V LSV and Koutecky-Levich plots of $\mathrm{Co}_{x} \mathrm{Fe}_{1-x} \mathrm{Se}_{2}, \mathrm{Co}_{x} \mathrm{Ni}_{1-x} \mathrm{Se} 2$ and $\mathrm{Pt} / \mathrm{C}$

VITafel polts of $\mathrm{Co}_{x} \mathrm{Fe}_{1-x} \mathrm{Se}_{2}, \mathrm{Co}_{x} \mathrm{Ni}_{1-x} \mathrm{Se}_{2}$ and $\mathrm{Pt} / \mathrm{C}$

VIILSV of Con.7 $\mathrm{Fe}_{0.3} \mathrm{Se}_{2}, \mathrm{Coo.7}_{\mathrm{N}} \mathrm{Ni}_{0.3 \mathrm{Se}}$ and $\mathrm{Pt} / \mathrm{C}$ against fuel crossover effects 
I The prepared materials corresponding to the precursors' amounts of $\mathrm{FeSO}_{4} \cdot 7 \mathrm{H}_{2} \mathrm{O}$ and $\mathrm{Ni}\left(\mathrm{NO}_{3}\right)_{2} \cdot 6 \mathrm{H}_{2} \mathrm{O}$

\section{Table S1}

The amounts of $\mathrm{FeSO}_{4} \cdot 7 \mathrm{H}_{2} \mathrm{O}$

\begin{tabular}{cc}
\hline Material number & $\mathrm{FeSO}_{4} \cdot 7 \mathrm{H}_{2} \mathrm{O}(\mathrm{g})$ \\
\hline $\mathrm{Co}_{0 .} \mathrm{Fe}_{0.1} \mathrm{Se}_{2}$ & 0.030 \\
$\mathrm{Co}_{0.8} \mathrm{Fe}_{0.2} \mathrm{Se}_{2}$ & 0.070 \\
$\mathrm{Co}_{0.7} \mathrm{Fe}_{0.3} \mathrm{Se}_{2}$ & 0.120 \\
$\mathrm{Co}_{0.6} \mathrm{Fe}_{0.4} \mathrm{Se}_{2}$ & 0.185 \\
$\mathrm{Co}_{0.5} \mathrm{Fe}_{0.5} \mathrm{Se}_{2}$ & 0.278 \\
\hline
\end{tabular}

\section{Table S2}

The amounts of $\mathrm{Ni}\left(\mathrm{NO}_{3}\right)_{2} \cdot 6 \mathrm{H}_{2} \mathrm{O}$

\begin{tabular}{cc}
\hline Material number & $\mathrm{Ni}\left(\mathrm{NO}_{3}\right)_{2} \cdot 6 \mathrm{H}_{2} \mathrm{O}(\mathrm{g})$ \\
\hline $\mathrm{Co}_{0 .} \mathrm{Ni}_{0.1} \mathrm{Se}_{2}$ & 0.032 \\
$\mathrm{Co}_{0.8} \mathrm{Ni}_{0.2} \mathrm{Se}_{2}$ & 0.073 \\
$\mathrm{Co}_{0.7} \mathrm{Ni}_{0.3} \mathrm{Se}_{2}$ & 0.125 \\
$\mathrm{Co}_{0.6} \mathrm{Ni}_{0.4} \mathrm{Se}_{2}$ & 0.194 \\
$\mathrm{Co}_{0.5} \mathrm{Ni}_{0.5} \mathrm{Se}_{2}$ & 0.291 \\
\hline
\end{tabular}




\section{CVs, LSV and Nyquist plots of $\mathrm{Co}_{x} \mathrm{Fe}_{1-x} \mathrm{Se}_{2}$ and $\mathrm{Co}_{x} \mathrm{Ni}_{1-x} \mathrm{Se}_{2}$}

Fig. S2 showed CVs, LSV, and Nyquist plots of $\mathrm{Co}_{x} \mathrm{Fe}_{1-x} \mathrm{Se}_{2}$ and $\mathrm{Co}_{x} \mathrm{Ni}_{1-x} \mathrm{Se}_{2}$ with different iron or nickel contents in $\mathrm{O}_{2}$-saturated $0.5 \mathrm{M} \mathrm{H}_{2} \mathrm{SO}_{4}$. Obviously, the electrocatalytic activities of $\mathrm{Co}_{0.7} \mathrm{Fe}_{0.3} \mathrm{Se}_{2}$ and $\mathrm{Co}_{0.7} \mathrm{Ni}_{0.3} \mathrm{Se}_{2}$ were better than others.
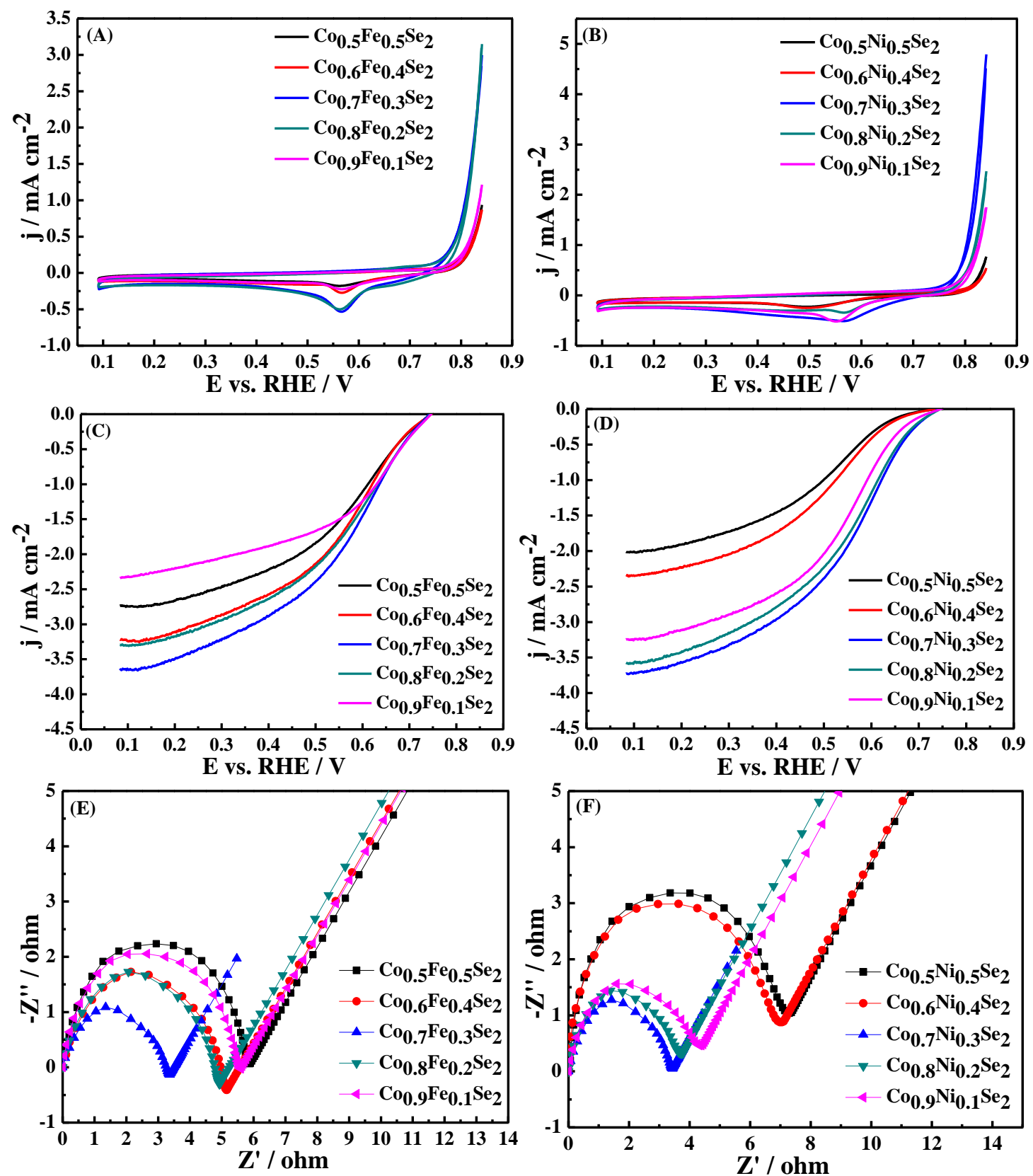

Fig. S2 CVs and LSV curves of (A, C) $\mathrm{Co}_{x} \mathrm{Fe}_{1-x} \mathrm{Se}_{2}$ and (B, D) $\mathrm{Co}_{x} \mathrm{Ni}_{1-x} \mathrm{Se}_{2}$ with different iron or nickel contents in $\mathrm{O}_{2}$-saturated $0.5 \mathrm{M} \mathrm{H}_{2} \mathrm{SO}_{4}$ at a scan rate of $10 \mathrm{mV}$ $\mathrm{s}^{-1}$. Nyquist plots of (E) $\mathrm{Co}_{x} \mathrm{Fe}_{1-x} \mathrm{Se}_{2}$ and (F) $\mathrm{Co}_{x} \mathrm{Ni}_{1-x} \mathrm{Se}_{2}$ with different iron or nickel contents in $\mathrm{O}_{2}$-saturated $0.5 \mathrm{M} \mathrm{H}_{2} \mathrm{SO}_{4}$ at open potential, frequency range: $1-10^{6} \mathrm{~Hz}$. 


\section{IIIXPS spectra of $\mathrm{Coo}_{.7} \mathrm{Ni}_{0.3 \mathrm{Se}}$}

Fig. S3 showed XPS spectra of the $\mathrm{Co}_{0.7} \mathrm{Ni}_{0.3} \mathrm{Se}_{2}$. The binding energies of Co $2 \mathrm{p}_{3 / 2}$ (780.3 eV, Fig. S3 (A)) and Ni 2p3/2 (855.1 eV, Fig. S3 (B)) were much higher than $\mathrm{CoSe}_{2}\left(\mathrm{Co} 2 \mathrm{p}_{3 / 2}=778.7 \mathrm{eV}\right)$ and nickel diselenide $\left(\mathrm{NiSe}_{2}, \mathrm{Ni} 2 \mathrm{p}_{3 / 2}=853.1 \mathrm{eV}\right)$. However, selenium shifts to negative binding energy of Se $3 \mathrm{~d}_{5 / 2}$ (Fig. S3 (C)) compared to $\mathrm{CoSe}_{2}\left(\mathrm{Se} 3 \mathrm{~d}_{5 / 2}=54.4 \mathrm{eV}\right)$, indicating that it was a complete ternary chalcogenide.
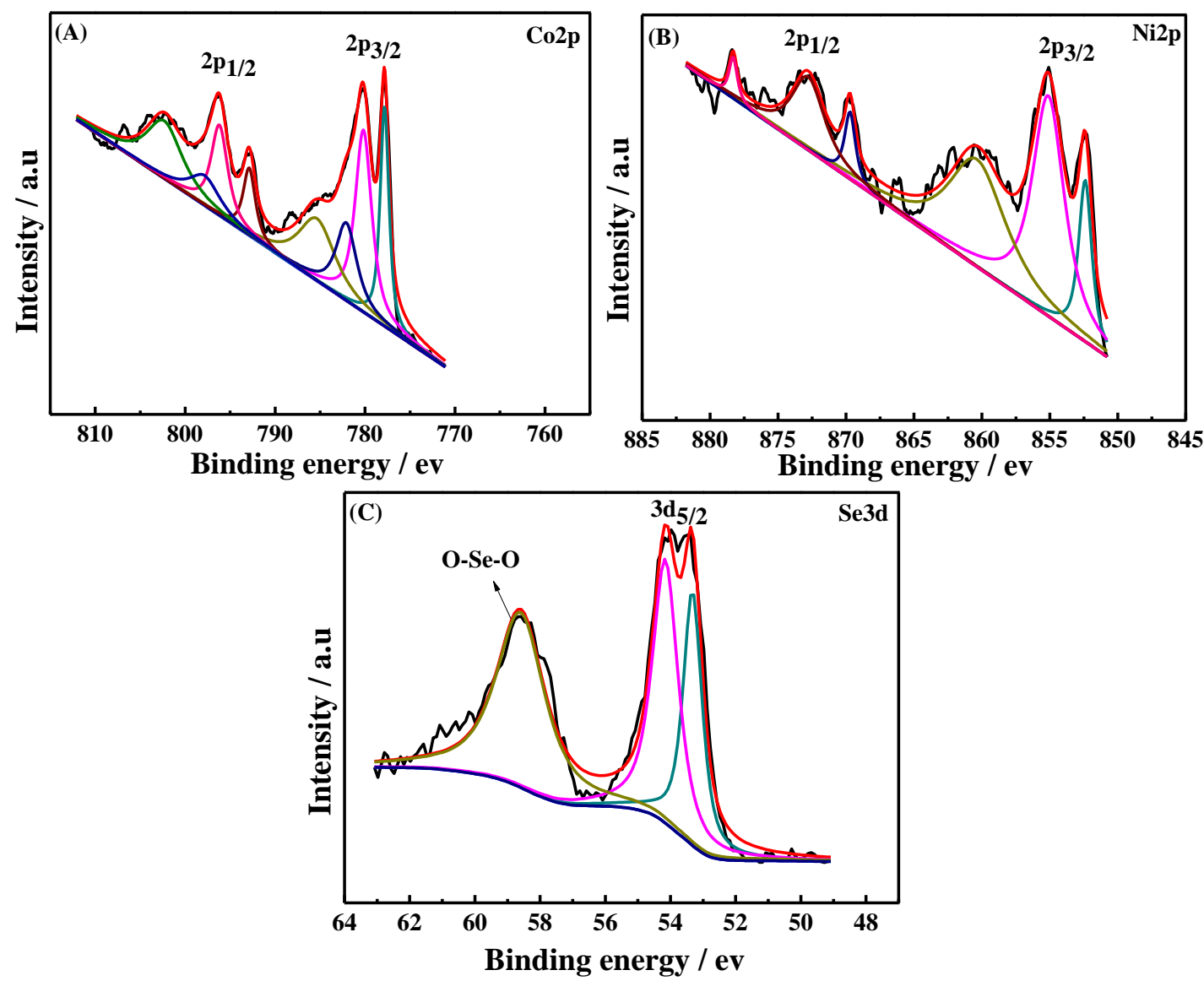

Fig. S3 XPS spectra of $\mathrm{Co}_{0.7} \mathrm{Ni}_{0.3} \mathrm{Se}_{2}$ in the (A) Co 2p, (B) Ni 2p and (C) Se $3 d$ regions. 
IVSEM of Co0.9Fe0.1Se $\mathrm{Co}_{2}, \mathrm{Cre}_{0.5} \mathrm{Se}_{2}, \mathrm{Co}_{.9} \mathrm{Ni}_{0.1} \mathrm{Se}_{2}$ and $\mathrm{Co}_{.5} \mathrm{Ni}_{0.5} \mathrm{Se}_{2}$

Fig. S4 showed SEM of (A) $\mathrm{Co}_{0.9} \mathrm{Ni}_{0.1} \mathrm{Se}_{2}$, (B) $\mathrm{Co}_{0.5} \mathrm{Ni}_{0.5} \mathrm{Se}_{2}$, (C) $\mathrm{Co}_{0.9} \mathrm{Fe}_{0.1} \mathrm{Se}_{2}$ and (D) $\mathrm{Co}_{0.5} \mathrm{Fe}_{0.5} \mathrm{Se}_{2}$. Obviously, all of the catalysts showed agglomerated surface and fluffy cotton-like microstructure. Furthermore, when the contents of doped Fe or Ni were higher, the morphology showed more agglomerated.
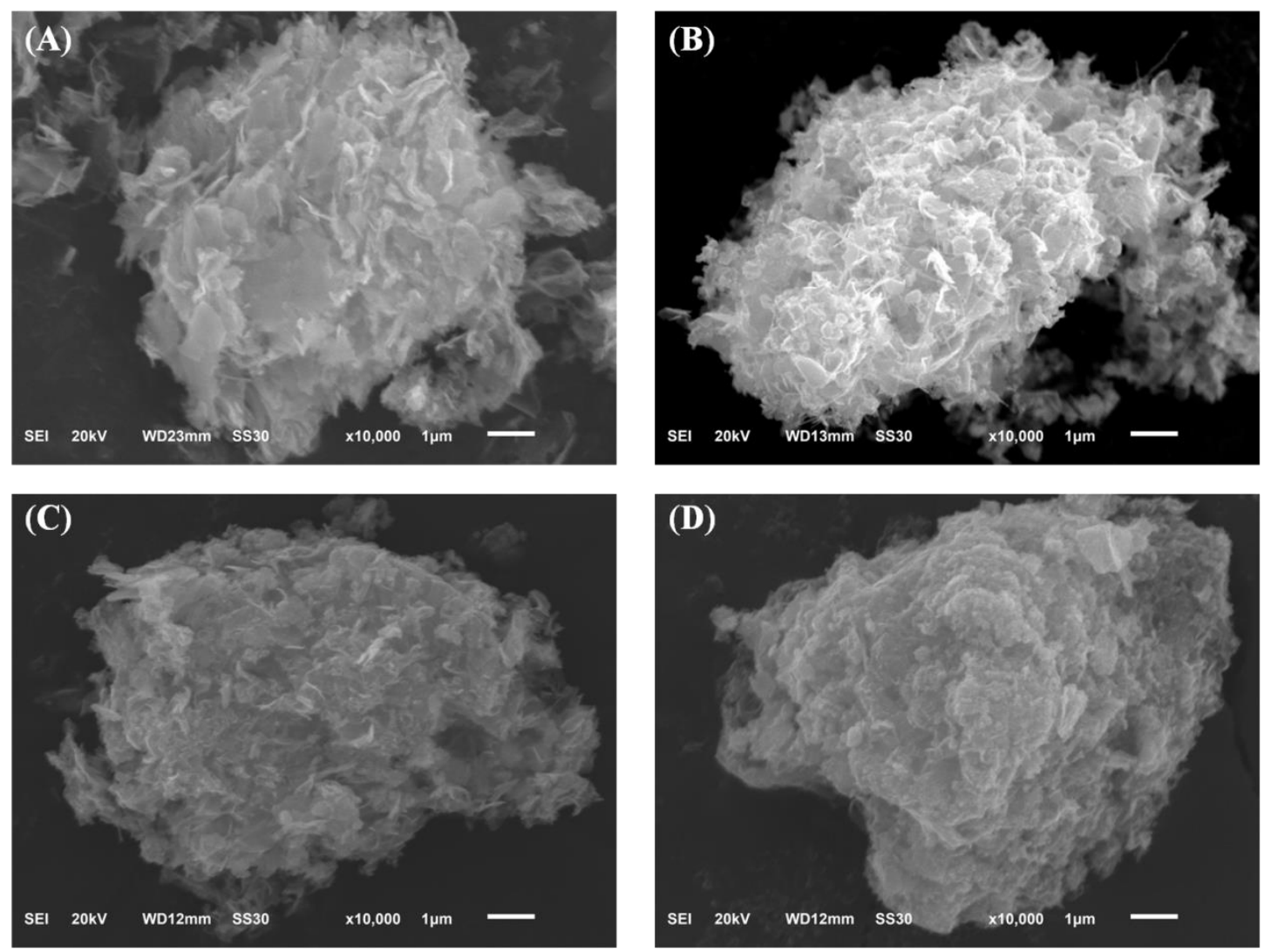

Fig. S4 SEM images of (A) $\mathrm{Co}_{0.9} \mathrm{Ni}_{0.1} \mathrm{Se}_{2}$, (B) $\mathrm{Co}_{0.5} \mathrm{Ni}_{0.5} \mathrm{Se}_{2}$, (C) $\mathrm{Co}_{0 .} \mathrm{Fe}_{0.1} \mathrm{Se}_{2}$ and (D) $\mathrm{Co}_{0.5} \mathrm{Fe}_{0.5} \mathrm{Se}_{2}$. 


\section{VLSV and Koutecky-Levich plots of $\mathrm{Co}_{x} \mathrm{Fe}_{1-x} \mathrm{Se}_{2}, \mathrm{Co}_{x} \mathrm{Ni}_{1-x} \mathrm{Se}_{2}$ and Pt/C}

Fig. S5 showed LSV of $\mathrm{Co}_{x} \mathrm{Fe}_{1-x} \mathrm{Se}_{2}$ and $\mathrm{Co}_{x} \mathrm{Ni}_{1-x} \mathrm{Se}_{2}$ with different iron or nickel contents at different rotating rate. Obviously, the diffusion currents were enhanced with increasing rotating rate. The corresponding Koutecky-Levich plots showed good linearity at various potentials. Except for $\mathrm{Co}_{0.7} \mathrm{Ni}_{0.3} \mathrm{Se}_{2}$ (Fig S5 (G)) and Pt/C (Fig S5 (J)) showed $4 \mathrm{e}^{-}$ORR process, other catalysts involved mixed four-electron and two-electron reduction processes with $\mathrm{H}_{2} \mathrm{O}_{2}$ as the intermediate agent.
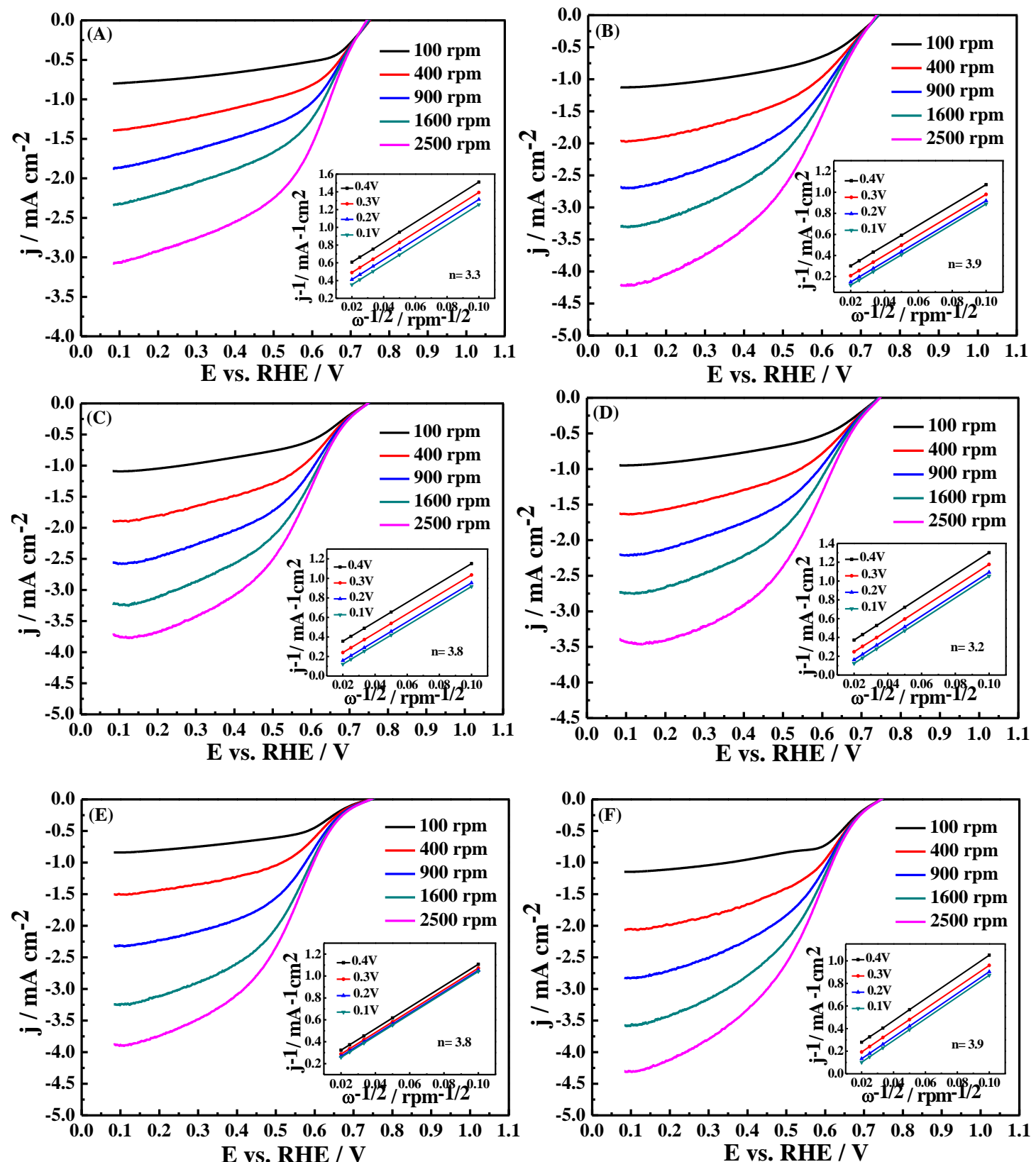

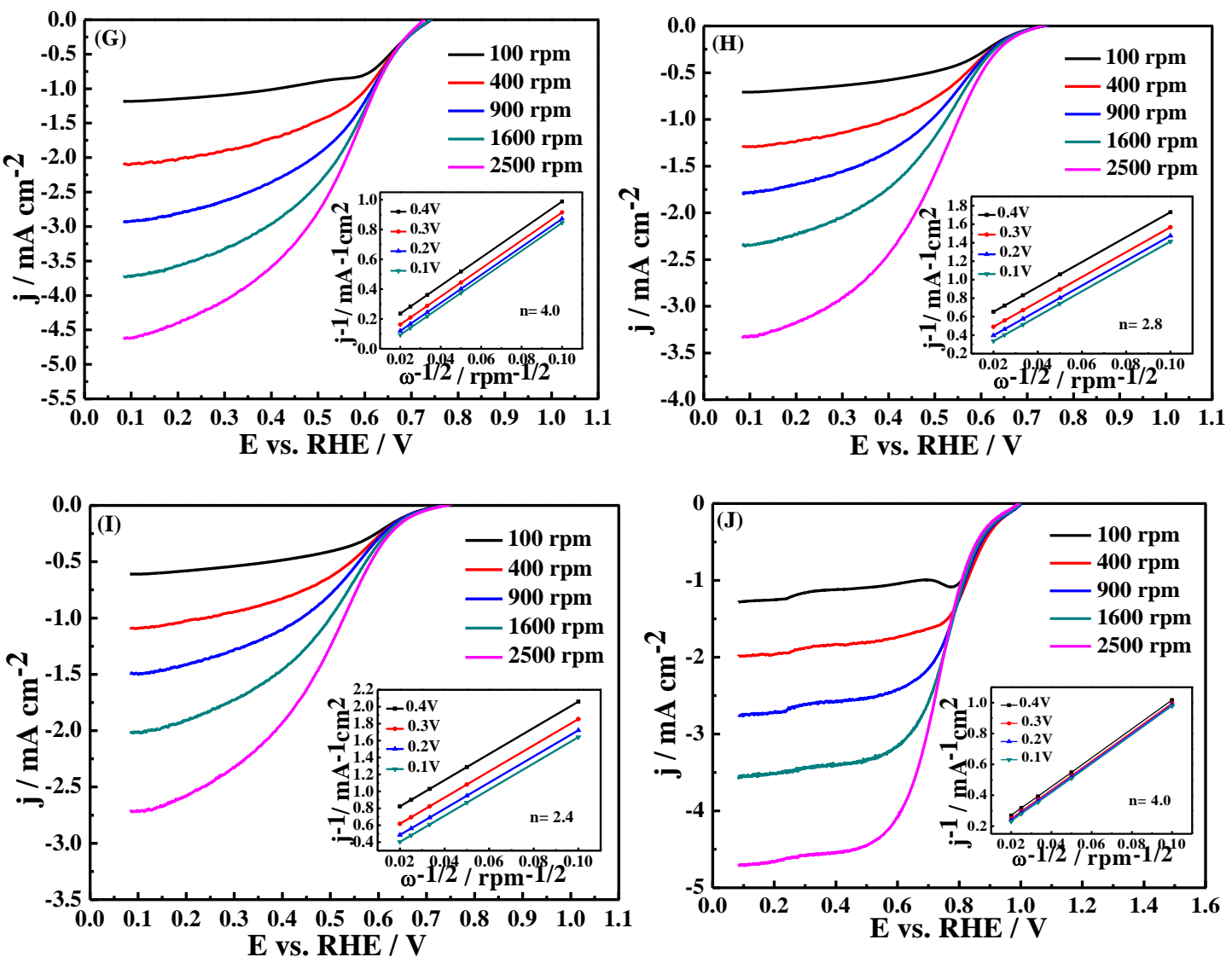

Fig. S5 LSV curves of (A) $\mathrm{Co}_{0.9} \mathrm{Fe}_{0.1} \mathrm{Se}_{2}$, (B) $\mathrm{Co}_{0.8} \mathrm{Fe}_{0.2} \mathrm{Se}_{2}$, (C) $\mathrm{Co}_{0.6} \mathrm{Fe}_{0.4} \mathrm{Se}_{2}$, (D) $\mathrm{Co}_{0 .} \mathrm{Fe}_{0.5} \mathrm{Se}_{2}$, (E) $\mathrm{Co}_{0.9} \mathrm{Ni}_{0.1} \mathrm{Se}_{2}$, (F) $\mathrm{Co}_{0.8} \mathrm{Ni}_{0.2} \mathrm{Se}_{2}$, (G) $\mathrm{Co}_{0.7} \mathrm{Ni}_{0.3} \mathrm{Se}_{2},(\mathrm{H}) \mathrm{Co}_{0.6} \mathrm{Ni}_{0.4} \mathrm{Se}_{2}$, (I) $\mathrm{Co}_{0.5} \mathrm{Ni}_{0.5} \mathrm{Se}_{2}$ and (J) $\mathrm{Pt} / \mathrm{C}$ in $\mathrm{O}_{2}$-saturated $0.5 \mathrm{M} \mathrm{H}_{2} \mathrm{SO}_{4}$ at various rotation rates, the Koutecky-Levich plots were shown in corresponding inset.

\section{VITafel polts of $\mathrm{Co}_{x} \mathrm{Fe}_{1-x} \mathrm{Se}_{2}, \mathrm{Co}_{x} \mathrm{Ni}_{1-x} \mathrm{Se}_{2}$ and $\mathrm{Pt} / \mathrm{C}$}

Fig. S6 showed the tafel plots of the $\mathrm{Co}_{x} \mathrm{Fe}_{1-x} \mathrm{Se}_{2}$ (Fig. S6 (A)) and $\mathrm{Co}_{x} \mathrm{Ni}_{1-x} \mathrm{Se}_{2}(\mathrm{Fig}$. S6 (C)) with different iron or nickel contents, and Pt/C (Fig. S6 (E)). In addition to $\mathrm{Pt} / \mathrm{C}$, Tafel slopes of $\mathrm{Co}_{0.7} \mathrm{Fe}_{0.3} \mathrm{Se}_{2}(110 \mathrm{mV} /$ decade $)$ were smallest than others. The electron transfer number (n) and calculated kinetic-limited current density $\left(j_{k}\right)$ value of different catalysts were clearly drawn in Fig. S6 (B) and (D). Co ${ }_{0.7} \mathrm{Fe}_{0.3} \mathrm{Se}_{2}$ exhibited the highest $j_{k}$ value of $1.83 \mathrm{~mA} \mathrm{~cm}{ }^{-2}$ at $0.30 \mathrm{~V}$ than other $\mathrm{Co}_{x} \mathrm{Fe}_{1-x} \mathrm{Se}_{2}$ and $\mathrm{Co}_{x} \mathrm{Ni}_{1-x} \mathrm{Se}_{2}$ catalysts. 

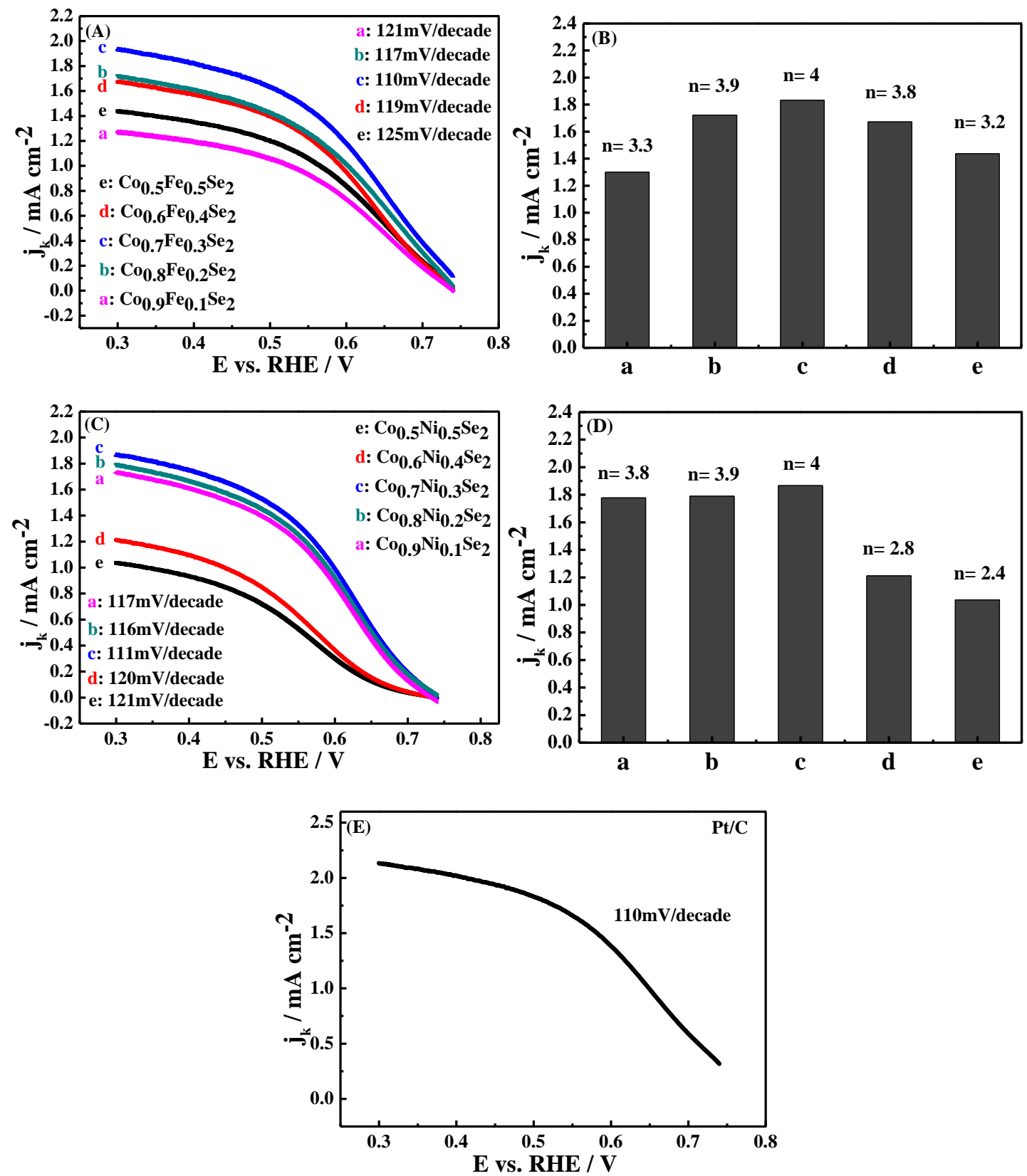

Fig. S6 Tafel polts of (A) $\mathrm{Co}_{x} \mathrm{Fe}_{1-x} \mathrm{Se}_{2}$ and (C) $\mathrm{Co}_{x} \mathrm{Ni}_{1-x} \mathrm{Se}_{2}$ with different iron or nickel contents at $1600 \mathrm{rpm}$, and Pt/C (E). (B, D) Electrons transfer number (n) and kinetic limiting current density (jk of (a) $\mathrm{Co}_{0.9} \mathrm{Fe}_{0.1} \mathrm{Se}_{2}$, (b) $\mathrm{Co}_{0.8} \mathrm{Fe}_{0.2} \mathrm{Se}_{2}$, (c) $\mathrm{Co}_{0.7} \mathrm{Fe}_{0.3} \mathrm{Se}_{2}$, (d) $\mathrm{Co}_{0.6} \mathrm{Fe}_{0.4} \mathrm{Se}_{2}$ and (e) $\mathrm{Co}_{0.5} \mathrm{Fe}_{0.5} \mathrm{Se}_{2}$ and (a) $\mathrm{Co}_{0 .} \mathrm{Ni}_{0.1} \mathrm{Se}_{2}$, (b) $\mathrm{Co}_{0.8} \mathrm{Ni}_{0.2} \mathrm{Se}_{2}$, (c) $\mathrm{Co}_{0.7} \mathrm{Ni}_{0.3} \mathrm{Se}_{2}$, (d) $\mathrm{Co}_{0.6} \mathrm{Ni}_{0.4} \mathrm{Se}_{2}$ and (e) $\mathrm{Co}_{0.5} \mathrm{Ni}_{0.5} \mathrm{Se}_{2}$ at $0.3 \mathrm{~V}$, respectively. 
VIILSV of $\mathrm{Co}_{.7} \mathrm{Fe}_{0.3} \mathrm{Se}_{2}, \mathrm{Co}_{.7} \mathrm{Ni}_{0.3} \mathrm{Se}_{2}$ and $\mathrm{Pt} / \mathrm{C}$ against fuel crossover effects

Fig. S7 showed LSV of Pt/C (A, B, G), $\mathrm{Co}_{0.7} \mathrm{Fe}_{0.3} \mathrm{Se}_{2}(\mathrm{C}, \mathrm{E})$ and $\mathrm{Co}_{0.7} \mathrm{Ni}_{0.3} \mathrm{Se}_{2}(\mathrm{D}$,

F) in $\mathrm{O}_{2}$-saturated $0.5 \mathrm{M} \mathrm{H}_{2} \mathrm{SO}_{4}$ containing different concentrations of $\mathrm{CH}_{3} \mathrm{OH}$, $\mathrm{C}_{2} \mathrm{H}_{5} \mathrm{OH}$ and $\left(\mathrm{CH}_{2} \mathrm{OH}\right)_{2}$. Obviously, $\mathrm{Co}_{0.7} \mathrm{Ni}_{0.3} \mathrm{Se}_{2}$ and $\mathrm{Co}_{0.7} \mathrm{Fe}_{0.3} \mathrm{Se}_{2}$ exhibited strong ability to avoid ethanol and ethylene glycol crossover effects.
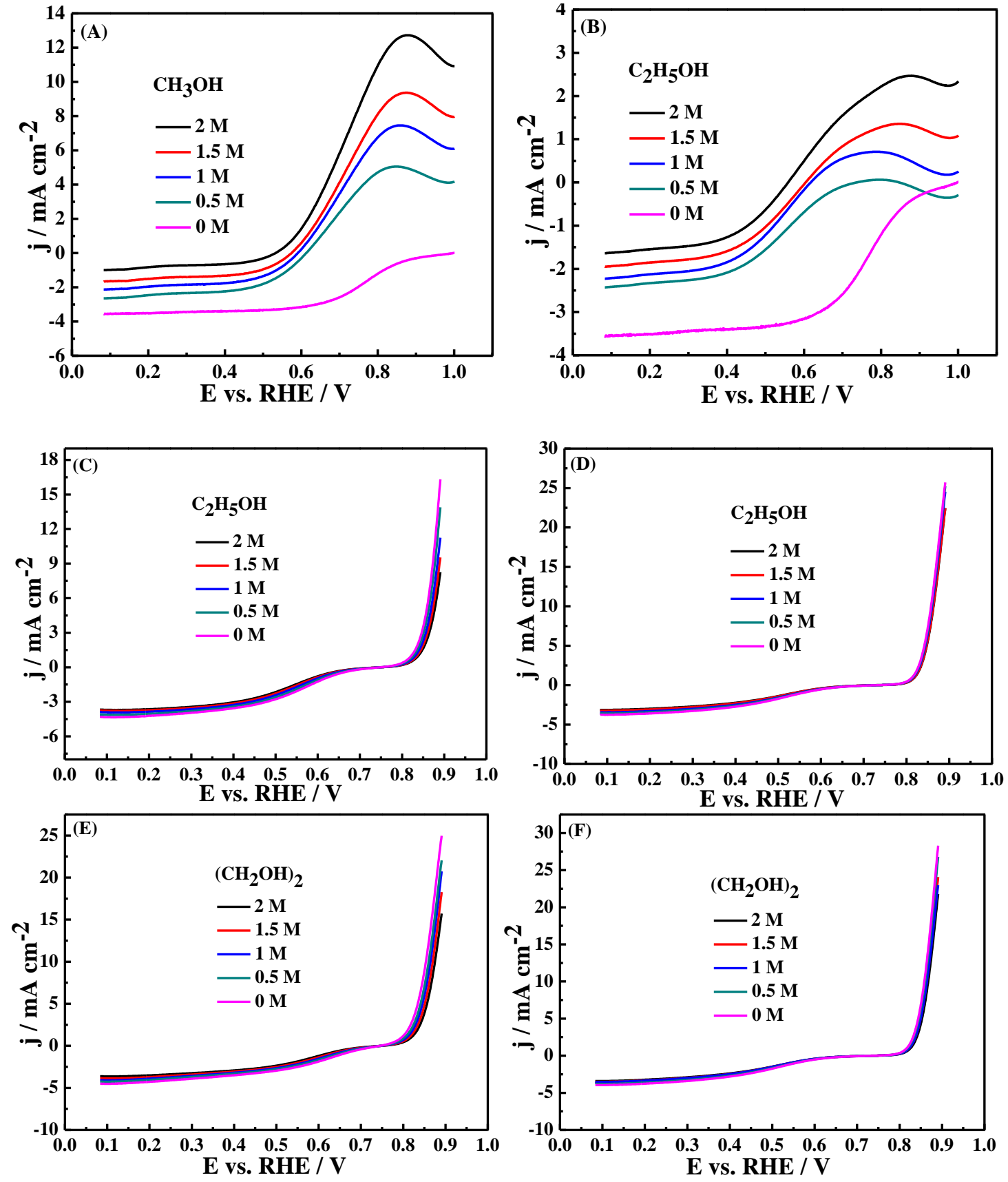


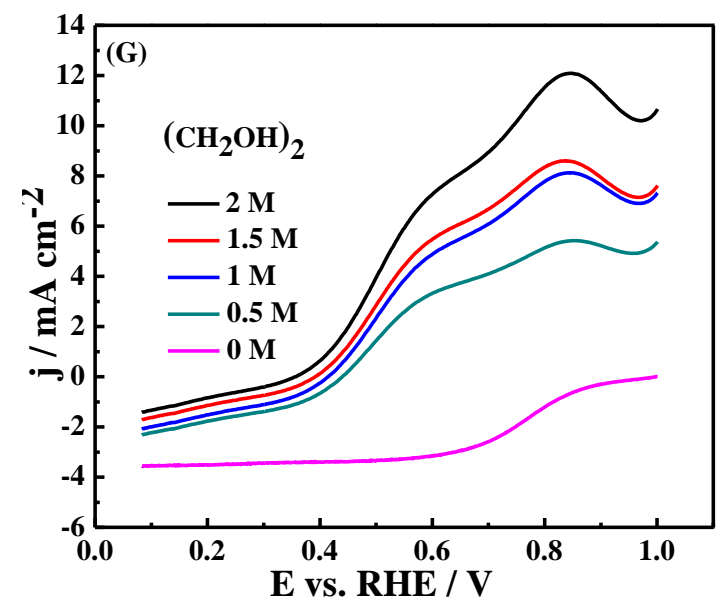

Fig. S7 LSV of (A, B, G) Pt/C, (C, E) $\mathrm{Co}_{0.7} \mathrm{Fe}_{0.3} \mathrm{Se}_{2}$ and (D, F) $\mathrm{Co}_{0.7} \mathrm{Ni}_{0.3} \mathrm{Se}_{2}$ in $\mathrm{O}_{2}$-saturated $0.5 \mathrm{M} \mathrm{H}_{2} \mathrm{SO}_{4}$ containing different concentrations of $\mathrm{CH}_{3} \mathrm{OH}, \mathrm{C}_{2} \mathrm{H}_{5} \mathrm{OH}$ and $\left(\mathrm{CH}_{2} \mathrm{OH}\right)_{2}$. 